\title{
The Verticillium wilt problem in Australian cotton
}

1 P Dadd-Daigle ${ }^{1,2}, \mathrm{~K} \mathrm{Kirkby}^{3}$, P Roy Chowdhury ${ }^{2}$, M Labbate $^{2}$ and T. A. Chapman ${ }^{1}$

$2 \quad{ }^{1}$ NSW Department of Primary Industries, Biosecurity and Food Safety, Elizabeth

3 Macarthur Agriculture Institute, Woodbridge Road, Menangle, NSW, 2568

$4 \quad{ }^{2}$ School of Life Sciences, The University of Technology Sydney, Harris Street,

5 Ultimo, NSW, 2007

$6 \quad{ }^{3}$ NSW Department of Primary Industries, Biosecurity and Food Safety, Kamilaroi

7 Highway, Narrabri, NSW, 2390

8

9 Corresponding author Dr Toni Chapman: toni.chapman@dpi.nsw.gov.au

11 Abstract

12 Verticillium dahliae is a soil-borne phytopathogen and the causal agent of

13 Verticillium wilt. It affects many agriculturally important crops around the world,

14 including cotton. In Australia, the billion-dollar cotton industry is increasingly

15 impacted by Verticillium wilt. Internationally it has been reported that the defoliating

16 V. dahliae Vegetative Compatibility Group (VCG) 1A causes severe damage to

17 cotton. In Australia however, the non-defoliating VCG2A is causing more severe

18 damage to crops in fields than the defoliating VCG1A. This review examines the

19 current research to understand the Australian $V$. dahliae situation, including current

20 classification systems, genetic analyses and management strategies. It appears that

21 virulence cannot be defined solely by VCG in Australian Verticillium dahliae isolates

22 causing disease in cotton, and that the industry must continually adapt their practices

23 in order to keep the disease under control. 
Verticillium; cotton; Gossypium hirsutum; V. dahliae

\section{Introduction}

29 In Australia, cotton is a growing billion-dollar industry. Cotton yields have increased

30 from $500 \mathrm{~kg}$ per hectare in the 1960's to $2000 \mathrm{~kg}$ per hectare in 2013 (Hamilton

31 2016). Cotton crops are largely furrow irrigated, grown on alkaline clay soils and tend

32 to be located near flood plains. There is often reduced or minimum tillage, tail-water

33 recirculated and in some areas permanent bed systems (Kirkby et al. 2013).

34 Sustainability and growth of the cotton industry is reliant on improved cotton

35 varieties, management of soil and water resources, and control of weeds, insect and 36 diseases (Constable 2004). Although Verticillium wilt in Australian cotton is 37 generally well managed, other countries have seen economic losses of $50 \%$ or more 38 (Wu and Subbarao 2014). The average incidence levels of Verticillium wilt caused by $39 V$. dahliae in Australian cotton are relatively low but yield losses can vary between 10 40 and $62 \%$ in some fields (Holman et al. 2016). However, the recent discovery of the 41 defoliating VCG1A and the disease severity of the non-defoliating VCG2A present an 42 additional problem for management of Verticillium wilt as incidences rise (Chapman 43 et al. 2016; Dadd-Daigle et al. 2020; Jensen and Redfern 2017; Kirkby et al. 2013).

44 Hence, Verticillium wilt is becoming a major concern for the Australian cotton 45 industry.

Verticillium dahliae

48 Verticillium encompasses a group of soil-borne ascomycetes. As of 2011, ten

49 Verticillium species have been described (Inderbitzin et al. 2011), including $V$. 
dahliae, the main causal agent of Verticillium wilt. Verticillium dahliae is responsible

51 for disease in over 400 plant species across the world. These include many

52 economically important crops such as olives, tomatoes, potatoes, lettuce and cotton

53 (Bhat and Subbarao 1999; Inderbitzin et al. 2011).

54

55 The life cycle of $V$. dahliae allows it to persist on farms for many years. It survives in soil in highly melanised resistant structures, known as microsclerotia, for over 10 years (Davis et al. 1994; Klosterman et al. 2009). These microsclerotia germinate in the presence of host plants, producing hyphae that penetrate the root cortex and reach the xylem. As hyphae and conidia grow within the xylem, the plant host can express symptoms of wilting, necrosis and leaf discolouration (Klimes et al. 2015). As symptoms progress, $V$. dahliae enters a saprophytic phase where the infection expands to other tissues, such as leaves, and a mass production of microsclerotia occurs. The extent of symptoms can depend on the susceptibility of the host and the infecting strain of $V$. dahliae. While some plants suffer severe wilting and necrosis, other infections are less severe, allowing the plant to recover (Daayf 2015).

66

67 Historically, the characterisation and classification of $V$. dahliae has been based on 68 the symptoms exhibited by the host plant, or by the interaction of pathogen virulence

69 and host resistance genes. Consequently, this has led to the use of host-specific 70 terminology and classification, resulting in a number of different classification

71 systems. Verticillium dahliae strains infecting tomato and cotton are divided into

72 "races", classified by the presence or absence of the Avel gene (Hu et al. 2015;

73 Maruthachalam et al. 2010). Strains from cotton are also categorised into defoliating 74 (D) and non-defoliating (ND) pathotypes (Daayf et al. 1995). While the D and ND 
pathotypes largely align to races 1 and 2 , respectively, this is not true for all strains and the systems are generally not used interchangeably (Hu et al. 2015). Host-specific pathology groups also include "eggplant pathotype", "tomato pathotype", "mint pathotype" and "sweet pepper pathotype" (Dung et al. 2012; Komatsu et al. 2001; Papaioannou et al. 2013b). While these classifications are generally understood in studies that focus on strains infecting a single host type, complexity arises when investigating Verticillium strains independently of the plant host they infect.

Currently, there is only one system that classifies all $V$. dahliae strains into groups, known as Vegetative Compatibility Groups (VCGs).

\section{Vegetative Compatibility Groups (VCGs) in Verticillium dahliae}

VCGs are determined by strain interaction and describe the formation of prototrophic heterokaryons, a fusion of two genetically distinct cells that occurs when two hyphal cells meet (Puhalla and Mayfield 1974). While not molecularly characterised in $V$. dahliae, related fungal models have shown that two sets of gene loci, known as vic (vegetative incompatibility) and het (heterokaryon incompatibility) govern the process. For isolates to form a heterokaryon, the alleles at the het or vic loci must be identical (Jiménez-Gasco et al. 2013). In practice, the VCG determination process requires that $V$. dahliae strains are mutated to become nitrogen non-utilizing " $n i t$ mutants". Mutants strains, one or two with known and the other with an unknown VCG, are placed on opposite sides of a minimal media agar plate and monitored for signs of prototrophic growth. If the mutant isolates are able to form heterokaryons, which allow growth on minimal media, the unknown isolate is assigned the same VCG as the known isolate (Joaquim and Rowe 1990). This method has led to the identification of five VCGs in $V$. dahliae, namely, VCG1 2, 3, 4 and 6, with VCG1 
and VCG2 further characterised into A and B subgroups, and VCG4 into A, B and

101 AB (Papaioannou and Typas 2015; Strausbaugh 1993).

Vegetative Compatibility Groups have been used to track the evolution and

104 movement of $V$. dahliae. Several groups found that isolates within VCGs are

105 phylogenetically similar (Collado-Romero et al. 2006) or fit a clonal reproductive 106 model (Dung et al. 2013; Milgroom et al. 2014). Others argued that although isolates

107 of the same VCG may be genetically similar, they are often phylogenetically distant, 108 with members of different subgroups being more closely related (Jiménez-Gasco et al. 109 2013). In most instances VCGs are monophyletic, with some exceptions such as 110 VCG2B (Collado-Romero et al. 2008). Following these studies, the origin of the $V$. 111 dahliae species has been speculated to be in Europe (Short et al. 2015), while the 112 virulent VCG1A has been traced back to North America (Milgroom et al. 2016).

114 Different plant hosts are often associated with different $V$. dahliae VCGs. VCG2A is

115 known to be highly pathogenic to tomato (Tsror et al. 2001), VCG2B is highly 116 aggressive in mint (Dung et al. 2013), VCG4A is highly pathogenic to potato (El117 Bebany et al. 2013), and VCG1A is virulent in olives (Dervis et al. 2007). In cotton, it 118 has generally been reported that VCG1A causes significant damage while VCG2A 119 and VCG4B are less virulent, although there have been some reports of VCG2B 120 causing damage (Dervis and Bicici 2005; Dervis et al. 2008; Elena 1999; Jiménez121 Gasco et al. 2013; Korolev et al. 2001).

123 While VCGs are currently the most widespread method to describe $V$. dahliae 124 populations, the genetics behind VCGs in $V$. dahliae are not well understood. In their 
attempt to create a high-throughput VCG screening method, Papaioannou and Typas

126 (2015) also sought to understand the genetic relationship between the two, "strong"

127 and "weak", heterokaryon reactions observed. These authors found that weak

128 interactions tend to be unstable, but there is still a transfer of genetic material,

129 suggesting that they may be vegetatively compatible. Although many other studies

130 acknowledge that weak reactions occur, most regard only strong interactions as

131 compatible (Strausbaugh 1993). This could impact the reliability of results examining

132 relatedness amongst VCGs and highlights a need for a narrower classification system

133 that does not suffer from these issues. Additionally, as the VCG determination process

134 is labour intensive and time-consuming, several groups have attempted to develop

135 alternative methods (Collado-Romero et al. 2009; El-Bebany et al. 2013; Papaioannou

136 et al. 2013a). However, currently, no molecular method is as reliable as the traditional

137 method.

139 Verticillium dahliae in Australian cotton

140 Since 1983, Verticillium-infected plant samples have been collected and $V$. dahliae

141 isolates maintained and stored in the culture collection of the NSW Department of

142 Primary Industries (Kirkby et al. 2013). The average incidence of Verticillium wilt

143 has generally been low throughout NSW. The incidence rose from 5.5\% in 2013/2014

144 to $7.1 \%$ in $2014 / 2015$ and $6.3 \%$ in the $2015 / 2016$ season (Chapman et al. 2016).

145 Disease symptoms are becoming more severe in some patches of Verticillium wilt, 146 with yield reductions reported to be greater than 6 bales/ha. There are concerns that

147 this increase in severity is related to the ND VCG2A strain reported in 2014 (Dadd-

148 Daigle et al. 2020; Smith et al. 2014). 
150 It was previously thought that only one VCG type, ND VCG4B, was present in

151 Australia, but in 2014, ND VCG2A was identified (Smith et al. 2014). Following the

152 discovery of ND VCG2A, analysis of $V$. dahliae historical samples taken from the

153 NSW Department of Primary Industries culture collection revealed the presence of the

154 D VCG1A (Chapman et al. 2016). The D VCG1A has been the cause of severe

155 disease and crop loss overseas (Jiménez-Díaz et al. 2006). However, despite the

156 presence of VCG1A in the historical samples, typical VCG1A disease presentation,

157 including the typical crop losses and complete defoliation of infected plants, has not

158 been a widespread observation in Australia. It is not clear what is causing the

159 disparity between the severity of D VCG1A and ND VCG2A disease in Australia and

160 overseas. It is possible, given that VCG2A has been shown to infect weeds commonly

161 found on cotton fields (Yildiz et al. 2009), that VCG2A $V$. dahliae has simply become

162 the most prevalent strain on Australian cotton fields, amplified by the polyetic nature

163 of the pathogen, and has acquired the ability to defoliate cotton plants. However,

164 further analysis of the relationship of genetics to pathogenicity and disease severity in

165 Australian $V$. dahliae VCGs is required.

167 Insights from Verticillium dahliae genome sequencing

168 In 2011 the $V$. dahliae VdLs.17 and $V$. albo-atrum genomes were sequenced using the

169 whole genome shotgun approach via Sanger sequencing (Klosterman et al. 2011).

170 Although the two $\sim 33 \mathrm{Mb}$ genomes were highly similar, there were four $300 \mathrm{~kb}$

171 regions in $V$. dahliae which had no synteny with $V$. albo-atrum. These regions were

172 denoted "Lineage Specific" (LS) regions. The LS regions were found to be highly

173 repetitive and represented over $50 \%$ of all identifiable transposable elements

174 contained in $V$. dahliae. Faino et al. (2015) used PacBio long read sequences to create 
175 a "gapless" genome and have since suggested that there are problems with the initial

$176 V$. dahliae VdLs.17 sequence. These authors argue that their method of genome

177 assembly helps to prevent problems associated with repetitive regions that cause

178 issues when assembling shorter contigs. Using PacBio sequencing, the VdLs.17

179 genome was re-assembled. The newly constructed genome indicates that $12 \%$ is

180 composed of repetitive regions, four times higher than was previously thought.

181

182 With the availability of a $V$. dahliae reference genome, there is an increasing

183 understanding of what makes $V$. dahliae such an adaptable pathogen with a broad host

184 range. There are suggestions that transposons could be a major reason for the genomic

185 diversity observed and that they contribute to the $V$. dahliae "plastic genome" driving

186 adaption to new plant hosts (Amyotte et al. 2012; Faino et al. 2016). This is supported

187 by de Jonge et al. (2013) who compared the VdLs. 17 reference strain with $10 \mathrm{~V}$.

188 dahliae genomes taken from geographically separate regions and hosts. The study

189 revealed that despite the genomes being highly similar, chromosome rearrangements

190 had occurred between all strains. Using RNA-seq data and deletion studies, they

191 showed that effector genes present in the LS regions were important to the

192 development of disease (de Jonge et al. 2013; de Jonge et al. 2012), suggesting that

193 chromosome rearrangements and these LS regions could contribute to $V$. dahliae's

194 adaptation to new hosts. Jin et al. (2017) explored the organism's use of alternative

195 splicing and developed their own algorithms, alongside previously available software,

196 to analyse $V$. dahliae cDNA sequences for common splicing events. They found that

$197 V$. dahliae has one of the most sophisticated splicing systems in eukaryotes, outside of

198 animals, and believe that this alternative splicing could explain some of $V$. dahliae's

199 plasticity. 
201 There are an increasing number of studies suggesting that horizontal gene transfer

202 plays an important role in $V$. dahliae's success as a pathogen. An analysis of $V$.

203 dahliae isolated from cotton in China, revealed the presence of a virulence gene

204 believed to have originated in Fusarium oxysporum, a related fungal pathogen often

205 found infecting cotton on the same farm (Chen et al. 2017). Their deletion

206 experiments found that removal of this gene affected the ability of the $V$. dahliae

207 strain to infect cotton, but not lettuce or tomato, highlighting it's ability to acquire

208 new virulence genes as it expands to different hosts. There has also been evidence of

$209 V$. dahliae acquiring genes from the host plant and from bacteria (de Jonge et al.

210 2012; van Kooten et al. 2019). These studies used phylogenetic analysis to look for

211 candidate genes that are found outside the Verticillium spp. They found numerous

212 candidate genes of bacterial and plant origin, many of which could potentially aid $V$.

213 dahliae in getting past the host plant's defences.

215 Management strategies for the control of Verticillium wilt

216 The nature of $V$. dahliae infection makes elimination of the pathogen difficult,

217 however, multiple management strategies have been applied over the years. As the $V$.

218 dahliae life cycle is dependent on microsclerotia present in crop soil, currently the

219 two main strategies target either the soil itself, for example by soil fumigation, or the

220 plants through development of resistant varieties (Short et al. 2015). Soil fumigation

221 aims to eliminate microsclerotia in crop soil. Traditionally, methyl bromide was used

222 to control pathogen populations, but was classified as a Class 1 stratospheric, ozone-

223 depleting substance and international regulations dictated by the Montreal Protocol

224 now restrict the use of this chemical (Martin 2003). Multiple studies have explored 
225 alternatives, including green manures, anaerobic soil disinfection and anaerobic

226 digestion. Green manure is a method utilising volatile components from plant waste to

227 reduce the number of microsclerotia (Yohalem and Passey 2011). Anaerobic soil

228 disinfection uses microbial activity from agricultural or horticultural waste products,

229 combined with mulched plastics, to deplete available oxygen in soil, creating

230 anaerobic conditions to prevent fungal growth (Goud et al. 2004). Anaerobic

231 digestion uses liquid digestate, a by-product from biogas production, as a bio-fertiliser

232 to control microsclerotia levels (Wei et al. 2016). However, the suitability of these

233 methods in commercial processes is still questionable. While, green manures and

234 anaerobic digestion are still relatively new and understudied, the well-studied

235 variants, such as Brassica sp., are deemed insufficient (Neubauer et al. 2014) and

236 anaerobic soil disinfection is not currently economically viable (Wei et al. 2016).

238 Production of resistant cotton varieties is a key strategy in the prevention of

239 Verticillium wilt. The development of resistant varieties in Australia has been

240 ongoing for more than 30 years, with the release of Sicala V-1 in 1990, and Sicala V-

2412 in 1994 (Liu et al. 2013). Despite successes with Sicala V-2 and subsequent

242 varieties derived from it, the incidence of Verticillium wilt has continued to rise in

243 recent years (Kirkby et al. 2013). This could be linked to the temperature tolerance, as

244 currently the $V$. dahliae resistance in available cotton varieties breaks down when

245 temperatures drop below $22^{\circ} \mathrm{C}$ (Quinn et al. 2018). Although there is ongoing research

246 into Verticillium resistance (Li et al. 2018; Li et al. 2019; Zhang et al. 2018), the

247 development of new cotton varieties that provide adequate yield is slow, and the

248 current varieties do not provide a substantial increase in resistance (Dadd-Daigle et al.

249 2020). Also, without a rapid diagnostic system that classifies $V$. dahliae into groups 
meaningful for Australian cotton, it is difficult to develop targeted and effective strategies.

Currently, crop rotation is one of the methods used to help manage Verticillium wilt on cotton farms in Australia. Crop rotation is the practice of varying the successive crops in a particular field to assist in the control of disease and weed management. Each crop varies in its susceptibility to certain pathogens. The success of crop rotation relies on initial inoculum levels in the soil, the number of rotations with non-host crops and the wetting and drying cycles that assist in the breakdown of inoculum in the soil (Wheeler et al. 2019). For example, most cotton farmers rotate with barley or

260 sorghum as they are not listed as host crops for $V$. dahliae. While commodity prices 261 are the short-term driving force, farms with high disease levels are looking at rotation

262 to ensure cotton remains sustainable in the long term (K. Kirby, personal

263 communication, September 2016). The current recommendations to growers are long

264 rotations with moderate irrigation to reduce overall pathogen levels and prevent

265 widespread movement of the microsclerotia (Holman et al. 2016; Scheikowski et al. 266 2019).

268 The development of real-time PCR protocols to determine microsclerotial load from 269 soil samples should assist with managing crop rotation practices (Banno et al. 2011; 270 Gharbi et al. 2016). Removal of the rotational crop plant debris has also been shown 271 to reduce the number of microsclerotia in the soil, but does sacrifice soil health 272 (Chawla et al. 2012). However, the known host range of $V$. dahliae, both symptomatic 273 and asymptomatic, is expanding as the pathogen comes into contact with new plant 274 species. There have been instances where a symptomless host has exhibited extensive 
vascular colonization and so contributes to the microsclerotial load despite the lack of symptoms (Wheeler and Johnson 2016). This makes selection of a suitable rotation crop more complex and highlights the need for a better understanding of the genomics of $V$. dahliae. In some instances, after multiple years of crop rotation followed by a cotton crop, the incidence of Verticillium wilt rises to match those found on farms that have had continuous cotton growth (Wheeler et al. 2019).

282 Given that the current attempts to mitigate Verticillium wilt on cotton farms is 283 becoming increasingly ineffective, new strategies need to be explored for use in 284 Australia. One area that hasn't been well examined in Australian cotton is the use of 285 endophytes as a biological control. The idea behind this strategy is to pre-infect the 286 plants with a microbe that will inhabit the same niche as $V$. dahliae, preventing 287 infection by the pathogen. This has been explored with both bacterial and fungal 288 endophytes (Li et al. 2012). Vagelas and Leontopoulos (2015) used the less virulent $289 V$. nigrescens to take up the niche usually filled by $V$. dahliae, preventing the 290 infiltration of conidia by the more virulent species, while Yuan et al. (2017) looked at 291 using unrelated fungal species as seed treatments. Although both studies saw a 292 reduction in $V$. dahliae caused Verticillium wilt, the use of Penicillium 293 simplicissimum and Leptosphaeria sp. also saw an increase in cotton seed production 294 as the number of cotton bolls increased (Yuan et al. 2017). As endophytes have been 295 shown to be beneficial in other areas of crop sustainability, such as protection from 296 insect pests and abiotic stress (Lugtenberg et al. 2016), this area could be hugely 297 beneficial to the Australian cotton industry which is often heavily impacted by water 298 availability. 
301 Improving future understanding of the Verticillium wilt problem in Australia

302 The nature of Verticillium wilt in Australian cotton is an interesting problem. Large 303 patches of severe Verticillium wilt have been found to be caused by the ND VCG2A

304 (Dadd-Daigle et al. 2020; Jensen and Redfern 2017), which is contrary to reporting on

305 other cotton farms around the world. This could be dependent on factors other than 306 the isolate, such as the Australian environment, or the farming conditions, and is an 307 area that warrants further exploration. While studies to further examine the Australian 308 V. dahliae population are currently being conducted, no study to date has indicated 309 what causes the difference in disease potential between Australian and international 310 cotton crops. In addition, the genetic analyses are revealing an increasing number of 311 methods by which $V$. dahliae can adapt. It is no wonder that strategies that work some 312 of the time, such as crop rotation or the use of resistant varieties, are becoming less 313 effective (Kirkby et al. 2013; Wheeler et al. 2019).

315 There is an increasing need for new mitigation strategies or the development of new 316 cotton varieties resistant to Verticillium wilt. However, in order to create and 317 implement these strategies, the current classification system needs to be improved to 318 better represent the $V$. dahliae present on Australian cotton farms. Characterisation of 319 the genetics controlling virulence has improved the classification of VCGs within 320 related Fusarium sp. by increasing molecular clarity between isolates and developing 321 new classification systems (Carvalhais et al. 2019). Although there is still some 322 debate surrounding the best tools to diagnostically identify virulent Fusarium 323 oxysporum strains (Magdama et al. 2019), a similar molecular understanding could 324 improve the VCG classification system within $V$. dahliae by establishing narrower 
325 classifications or by implementing a new system based on virulence genes unrelated to VCGs.

328 Future research to improve Verticillium wilt on Australian cotton farms needs to

329 largely build on current research efforts. An improved system for quantification of

330 inoculum in soils and a better understanding of the inoculum to disease thresholds for

331 different VCGs can clarify the effectiveness of crop rotation (Wheeler et al. 2019).

332 While an improved understanding of the environmental conditions and how current

333 farming methods impact Verticillium wilt on Australian farms can help inform best

334 farming practices (Kirkby et al. 2013). It is only through continued development of

335 new tools and a better understanding of $V$. dahliae genetics to rapidly analyse

336 Verticillium wilt samples that growers may be able to stay ahead of the pathogen,

337 preventing a situation where yield loss due to disease outweighs potential yield.

\section{Acknowledgements}

340 This project is supported by funding from the Australian Government Department of

341 Agriculture as part of its Rural R\&D for Profit programme and the Cotton Research

342 and Development Corporation. Rosalie Daniel and John Webster reviewed and

343 improved an earlier version of this manuscript.

\section{References}

Amyotte SG, Tan X, Pennerman K, del Mar Jimenez-Gasco M, Klosterman SJ, Ma LJ, Dobinson KF, Veronese P (2012) Transposable elements in phytopathogenic Verticillium spp.: insights into genome evolution and inter- and intra-specific diversification BMC Genomics 13:1-20 doi:10.1186/1471-2164-13-314

Banno S, Saito H, Sakai H, Urushibara T, Ikeda K, Kabe T, Kemmochi I, Fujimura M (2011) Quantitative nested real-time PCR detection of Verticillium 
longisporum and $V$. dahliae in the soil of cabbage fields Journal of General Plant Pathology 77:282-291 doi:10.1007/s10327-011-0335-9

Bhat RG, Subbarao KV (1999) Host Range Specificity in Verticillium dahliae Phytopathology 89:1218-1225 doi:10.1094/PHYT0.1999.89.12.1218

Carvalhais LC, Henderson J, Rincon-Florez VA, O'Dwyer C, Czislowski E, Aitken EAB, Drenth A (2019) Molecular Diagnostics of Banana Fusarium Wilt Targeting Secreted-in-Xylem Genes Frontiers in Plant Science 10 doi:10.3389/fpls.2019.00547

Chapman TA, Chambers GA, Kirkby K, Jiménez-Díaz RM (2016) First report of the presence of Verticillium dahliae VCG1A in Australia Australasian Plant Disease Notes 11:1-4 doi:10.1007/s13314-016-0197-2

Chawla S, Woodward JE, Wheeler TA (2012) Influence of Verticillium dahliae Infested Peanut Residue on Wilt Development in Subsequent Cotton International Journal of Agronomy 2012:1-5 doi:10.1155/2012/212075

Chen JY, Liu C, Gui YJ, Si KW, Zhang DD, Wang J, Short Dylan PG, Huang JQ, Li NY, Liang Y, Zhang WQ, Yang L, Ma XF, Li TG, Zhou L, Wang BL, Bao YM, Subbarao Krishna V, Zhang GY, Dai XF (2017) Comparative genomics reveals cotton-specific virulence factors in flexible genomic regions in Verticillium dahliae and evidence of horizontal gene transfer from Fusarium New Phytologist 217:756-770 doi:10.1111/nph.14861

Collado-Romero M, Berbegal M, Jiménez-Díaz RM, Armengol J, Mercado-Blanco J (2009) A PCR-based 'molecular tool box' for in planta differential detection of Verticillium dahliae vegetative compatibility groups infecting artichoke Plant Pathology 58:515-526 doi:10.1111/j.13653059.2008.01981.x

Collado-Romero M, Mercado-Blanco J, Olivares-García C, Jiménez-Díaz RM (2008) Phylogenetic Analysis of Verticillium dahliae Vegetative Compatibility Groups Phytopathology® 98:1019-1028 doi:10.1094/PHYTO-98-9-1019

Collado-Romero M, Mercado-Blanco J, Olivares-García C, Valverde-Corredor A, Jiménez-Díaz RM (2006) Molecular Variability Within and Among Verticillium dahliae Vegetative Compatibility Groups Determined by Fluorescent Amplified Fragment Length Polymorphism and Polymerase Chain Reaction Markers Phytopathology 96:485-495 doi:10.1094/PHYTO-96-0485

Constable G (2004) Research's contribution to the evolution of the Australian cotton industry Proceedings of the 4th International Crop Science Congress Brisbane, Australia

Daayf F (2015) Verticillium wilts in crop plants: Pathogen invasion and host defence responses Can J Plant Pathol 37:8-20 doi:10.1080/07060661.2014.989908

Daayf F, Nicole M, Geiger J-P (1995) Differentiation of Verticillium dahliae populations on the basis of vegetative compatibility and pathogenicity on cotton European Journal of Plant Pathology 101:69-79 doi:10.1007/BF01876095

Dadd-Daigle P, Kirkby K, Collins D, Cuddy W, Lonergan P, Roser S, Chowdhury PR, Labbate M, Chapman TA (2020) Virulence not linked with vegetative compatibility groups in Australian cotton Verticillium dahliae isolates Australian Journal of Crop Science 14:633-640 
Davis JR, Pavek JJ, Corsini DL, Sorensen LH, Schneider AT, Everson DO, Westermann DT, Huisman OC (1994) Influence of continuous cropping of several potato clones on the epidemiology of Verticillium wilt of potato Phytopathology 84:207-214 doi:10.1094/Phyto-84-207

de Jonge R, Bolton MD, Kombrink A, van den Berg GCM, Yadeta KA, Thomma BPHJ (2013) Extensive chromosomal reshuffling drives evolution of virulence in an asexual pathogen Genome Research 23:1271-1282 doi:10.1101/gr.152660.112

de Jonge R, Peter van Esse H, Maruthachalam K, Bolton MD, Santhanam P, Saber MK, Zhang Z, Usami T, Lievens B, Subbarao KV, Thomma BPHJ (2012) Tomato immune receptor $V e 1$ recognizes effector of multiple fungal pathogens uncovered by genome and RNA sequencing Proceedings of the National Academy of Sciences 109:5110-5115 doi:10.1073/pnas.1119623109

Dervis S, Bicici M (2005) Vegetative compatibility groups in Verticillium dahliae isolates from cotton in Turkey Phytoparasitica 33:157-168 doi:10.1007/BF03029975

Dervis S, Erten L, Soylu S, Tok FM, Kurt S, Ylldız M, Soylu EM (2007) Vegetative compatibility groups in Verticillium dahliae isolates from olive in western Turkey European Journal of Plant Pathology 119:437-447 doi:10.1007/s10658-007-9183-z

Dervis S, Kurt S, Soylu S, Erten L, Mine Soylu E, Yıldız M, Tok FM (2008) Vegetative compatibility groups of Verticillium dahliae from cotton in the southeastern anatolia region of Turkey Phytoparasitica 36:74-83 doi:10.1007/BF02980750

Dung JKS, Peever TL, Johnson DA (2012) Verticillium dahliae Populations from Mint and Potato Are Genetically Divergent with Predominant Haplotypes Phytopathology® 103:445-459 doi:10.1094/PHYTO-06-12-0133-R

Dung JKS, Peever TL, Johnson DA (2013) Verticillium dahliae Populations from Mint and Potato Are Genetically Divergent with Predominant Haplotypes Phytopathology 103:445-459 doi:10.1094/PHYTO-06-12-0133-R

El-Bebany AF, Alkher H, Adam LR, Daayf F (2013) Vegetative compatibility of Verticillium dahliae isolates from potato and sunflower using nitrate nonutilizing (nit) mutants and PCR-based approaches Can J Plant Pathol 35:19 doi:10.1080/07060661.2012.702128

Elena K (1999) Genetic Relationships Among Verticillium dahliae Isolates from Cotton in Greece Based on Vegetative Compatibility European Journal of Plant Pathology 105:609-616 doi:10.1023/A:1008771112068

Faino L, Seidl MF, Datema E, van den Berg GC, Janssen A, Wittenberg AH, Thomma BP (2015) Single-Molecule Real-Time Sequencing Combined with Optical Mapping Yields Completely Finished Fungal Genome MBio 6:e00936-00915 doi:10.1128/mBio.00936-15

Faino L, Seidl MF, Shi-Kunne X, Pauper M, van den Berg GCM, Wittenberg AHJ, Thomma BPHJ (2016) Transposons passively and actively contribute to evolution of the two-speed genome of a fungal pathogen Genome Research 26:1091-1100 doi:10.1101/gr.204974.116

Gharbi Y, Barkallah M, Bouazizi E, Cheffi M, Krid S, Triki MA, Gdoura R (2016) Development and validation of a new real-time assay for the quantification of Verticillium dahliae in the soil: a comparison with 
conventional soil plating Mycological Progress 15:1-13

doi:10.1007/s11557-016-1196-6

Goud J-KC, Termorshuizen AJ, Blok WJ, van Bruggen AHC (2004) Long-Term Effect of Biological Soil Disinfestation on Verticillium Wilt Plant Disease 88:688-694 doi:10.1094/PDIS.2004.88.7.688

Hamilton D (2016) Reaping the benefits of innovation - the Australian cotton story Agricultural Science 28:18-24

Holman S, Kirkby K, Smith L, Hartnett H (2016) Vert update: The latest in vert research CottonInfo fact sheet September 2016

Hu X-P, Gurung S, Short DPG, Sandoya GV, Shang W-J, Hayes RJ, Davis RM, Subbarao KV (2015) Nondefoliating and Defoliating Strains from Cotton Correlate with Races 1 and 2 of Verticillium dahliae Plant Disease 99:1713-1720 doi:10.1094/PDIS-03-15-0261-RE

Inderbitzin P, Bostock RM, Davis RM, Usami T, Platt HW, Subbarao KV (2011) Phylogenetics and Taxonomy of the Fungal Vascular Wilt Pathogen Verticillium, with the Descriptions of Five New Species PLoS ONE 6:e28341 doi:10.1371/journal.pone.0028341

Jensen M, Redfern R (2017) Breaking the Verticillium cycle vol Winter 2017. Cotton Research and Development Corporation,

Jiménez-Díaz RM, Mercado-Blanco J, Olivares-García C, Collado-Romero M, Bejarano-Alcázar J, Rodríguez-Jurado D, Giménez-Jaime A, García-Jiménez J, Armengol J (2006) Genetic and Virulence Diversity in Verticillium dahliae Populations Infecting Artichoke in Eastern-Central Spain Phytopathology 96:288-298 doi:10.1094/PHYT0-96-0288

Jiménez-Gasco MdM, Malcolm GM, Berbegal M, Armengol J, Jiménez-Díaz RM (2013) Complex Molecular Relationship Between Vegetative Compatibility Groups (VCGs) in Verticillium dahliae: VCGs Do Not Always Align with Clonal Lineages Phytopathology 104:650-659 doi:10.1094/PHYT0-07-13-0180-R

Jin L, Li G, Yu D, Huang W, Cheng C, Liao S, Wu Q, Zhang Y (2017) Transcriptome analysis reveals the complexity of alternative splicing regulation in the fungus Verticillium dahliae BMC Genomics 18:130 doi:10.1186/s12864017-3507-y

Joaquim TR, Rowe RC (1990) Reassessment of Vegetative Compatibility relationships among strains of Verticillium dahliae using nitratenonutilizing mutants Phytopathology 80:1160-1166 doi: 10.1094/Phyto80-1160

Kirkby KA, Lonergan PA, Allen SJ (2013) Three decades of cotton disease surveys in NSW, Australia Crop and Pasture Science 64:774-779 doi:10.1071/CP13143

Klimes A, Dobinson KF, Thomma BPHJ, Klosterman SJ (2015) Genomics Spurs Rapid Advances in Our Understanding of the Biology of Vascular Wilt Pathogens in the Genus Verticillium Annual Review of Phytopathology 53:181-198 doi:10.1146/annurev-phyto-080614-120224

Klosterman SJ, Atallah ZK, Vallad GE, Subbarao KV (2009) Diversity, pathogenicity, and management of Verticillium species Annu Rev Phytopathol 47:39-62 doi:10.1146/annurev-phyto-080508-081748

Klosterman SJ, Subbarao KV, Kang S, Veronese P, Gold SE, Thomma BPHJ, Chen Z, Henrissat B, Lee Y-H, Park J, Garcia-Pedrajas MD, Barbara DJ, Anchieta A, 

de Jonge R, Santhanam P, Maruthachalam K, Atallah Z, Amyotte SG, Paz Z, Inderbitzin P, Hayes RJ, Heiman DI, Young S, Zeng Q, Engels R, Galagan J, Cuomo CA, Dobinson KF, Ma L-J (2011) Comparative Genomics Yields Insights into Niche Adaptation of Plant Vascular Wilt Pathogens PLoS pathogens 7:e1002137 doi:10.1371/journal.ppat.1002137

Komatsu T, Sumino A, Kageyama K (2001) Characterization of Verticillium dahliae Isolates from Potato on Hokkaido by Random Amplified Polymorphic DNA (RAPD) and REP-PCR Analyses Journal of General Plant Pathology 67:23-27 doi:10.1007/PL00012982

Korolev N, Pérez-Artés E, Bejarano-Alcázar J, Rodríguez-Jurado D, Katan J, Katan T, Jiménez-Díaz RM (2001) Comparative Study of Genetic Diversity and Pathogenicity Among Populations of Verticillium Dahliae from Cotton in Spain and Israel European Journal of Plant Pathology 107:443-456 doi:10.1023/A:1011212426447

Li CH, Shi L, Han Q, Hu HL, Zhao MW, Tang CM, Li SP (2012) Biocontrol of verticillium wilt and colonization of cotton plants by an endophytic bacterial isolate J Appl Microbiol 113:641-651 doi:10.1111/j.13652672.2012.05371.x

Li NY, Ma XF, Short DPG, Li TG, Zhou L, Gui YJ, Kong ZQ, Zhang DD, Zhang WQ, Li JJ, Subbarao KV, Chen JY, Dai XF (2018) The island cotton NBS-LRR gene GbaNA1 confers resistance to the non-race 1 Verticillium dahliae isolate Vd991 Molecular Plant Pathology 19:1466-1479 doi:10.1111/mpp.12630

Li ZK, Chen B, Li XX, Wang JP, Zhang Y, Wang XF, Yan YY, Ke HF, Yang J, Wu JH, Wang GN, Zhang GY, Wu LQ, Wang XY, Ma ZY (2019) A newly identified cluster of glutathione S-transferase genes provides Verticillium wilt resistance in cotton Plant J 98:213-227 doi:10.1111/tpj.14206

Liu S, Reid P, Stiller W, Constable G (2013) The contribution of new varieties to cotton yield improvement. CSIRO Plant Industry, Narrabri

Lugtenberg BJ, Caradus JR, Johnson LJ (2016) Fungal endophytes for sustainable crop production FEMS Microbiol Ecol 92 doi:10.1093/femsec/fiw194

Magdama F, Monserrate-Maggi L, Serrano L, Sosa D, Geiser DM, Jiménez-Gasco MdM (2019) Comparative analysis uncovers the limitations of current molecular detection methods for Fusarium oxysporum f. sp. cubense race 4 strains PLOS ONE 14:e0222727 doi:10.1371/journal.pone.0222727

Martin FN (2003) Development of alternative strategies for management of soilborne pathogens currently controlled with methyl bromide Annu Rev Phytopathol 41:325-350 doi:10.1146/annurev.phyto.41.052002.095514

Maruthachalam K, Atallah ZK, Vallad GE, Klosterman SJ, Hayes RJ, Davis RM, Subbarao KV (2010) Molecular Variation Among Isolates of Verticillium dahliae and Polymerase Chain Reaction-Based Differentiation of Races Phytopathology 100:1222-1230 doi:10.1094/PHYT0-04-10-0122

Milgroom MG, del Mar Jiménez-Gasco M, Olivares-García C, Jiménez-Díaz RM (2016) Clonal Expansion and Migration of a Highly Virulent, Defoliating Lineage of Verticillium dahliae Phytopathology 106:1038-1046 doi:10.1094/PHYTO-11-15-0300-R

Milgroom MG, Jiménez-Gasco MdM, Olivares García C, Drott MT, Jiménez-Díaz RM (2014) Recombination between Clonal Lineages of the Asexual Fungus Verticillium dahliae Detected by Genotyping by Sequencing PLoS ONE 9:e106740 doi:10.1371/journal.pone.0106740 
Neubauer C, Heitmann B, Müller C (2014) Biofumigation potential of Brassicaceae cultivars to Verticillium dahliae European Journal of Plant Pathology 140:341-352 doi:10.1007/s10658-014-0467-9

Papaioannou IA, Dimopoulou CD, Typas MA (2013a) Structural and phylogenetic analysis of the rDNA intergenic spacer region of Verticillium dahliae FEMS microbiology letters 347:23-32 doi:10.1111/1574-6968.12215

Papaioannou IA, Ligoxigakis EK, Vakalounakis DJ, Markakis EA, Typas MA (2013b) Phytopathogenic, morphological, genetic and molecular characterization of a Verticillium dahliae population from Crete, Greece European Journal of Plant Pathology 136:577-596 doi:10.1007/s10658013-0189-4

Papaioannou IA, Typas MA (2015) High-Throughput Assessment and Genetic Investigation of Vegetative Compatibility in Verticillium dahliae Journal of Phytopathology 163:475-485 doi:10.1111/jph.12345

Puhalla JE, Mayfield JE (1974) The Mechanism of Heterokaryotic Growth in Verticillium dahliae Genetics 76:411-422

Quinn J, Eveleigh R, Ford B, Millyard J, Teague C, Barry C, Lee S, Devlin A, McDonald C (2018) Verticillium Wilt. Facts on Friday vol October. Cotton Seed Distributors, Wee Waa, Australia

Scheikowski L, Smith L, Vadakattu G, Shuey T, Kafle D (2019) Longer rotations are required to reduce Verticillium where disease levels are high vol December18-January19.

Short DPG, Sandoya G, Vallad GE, Koike ST, Xiao C-L, Wu B-M, Gurung S, Hayes RJ, Subbarao KV (2015) Dynamics of Verticillium Species Microsclerotia in Field Soils in Response to Fumigation, Cropping Patterns, and Flooding Phytopathology 105:638-645 doi:10.1094/PHYT0-09-14-0259-R

Smith L, Scheikowski L, Bauer B, Lehane J, Allen S (2014) Detection of New Pathogens in Australian Cotton Cotton Research and Development Corporationon behalf of the 17th Australian Cotton Conference

Strausbaugh CA (1993) Assessment of Vegetative Compatibility and Virulence of Verticillium dahliae Isolates from Idaho Potatoes and Tester Strains Phytopathology 83:1253-1258

Tsror L, Hazanovsky M, Mordechi-Lebiush S, Sivan S (2001) Aggressiveness of Verticillium dahliae isolates from different vegetative compatibility groups to potato and tomato Plant Pathology 50:477-482 doi:10.1046/j.1365-3059.2001.00587.x

Vagelas I, Leontopoulos S (2015) Cross-protection of cotton against Verticillium wilt by Verticillium nigrescens Emirates Journal of Food and Agriculture 27:687-691 doi:10.9755/ejfa.2015-04-047

van Kooten M, Shi-Kunne X, Thomma BPHJ, Depotter JRL, Seidl MF (2019) The Genome of the Fungal Pathogen Verticillium dahliae Reveals Extensive Bacterial to Fungal Gene Transfer Genome Biology and Evolution 11:855868 doi:10.1093/gbe/evz040

Wei F, Passey T, Xu X (2016) Effects of individual and combined use of biofumigation-derived products on the viability of Verticillium dahliae microsclerotia in soil Crop Protection 79:170-176 doi:http://dx.doi.org/10.1016/j.cropro.2015.09.008 
Wheeler DL, Johnson DA (2016) Verticillium dahliae Infects, Alters Plant Biomass, and Produces Inoculum on Rotation Crops Phytopathology® 106:602-613 doi:10.1094/PHYTO-07-15-0174-R

Wheeler TA, Bordovsky JP, Keeling JW (2019) The effectiveness of crop rotation on management of Verticillium wilt over time Crop Protection 121:157162 doi:https://doi.org/10.1016/i.cropro.2019.03.021

Wu BM, Subbarao KV (2014) A Model for Multiseasonal Spread of Verticillium Wilt of Lettuce Phytopathology 104:908-917 doi:10.1094/PHYT0-12-130333-R

Yildiz A, Dogan M, Boz Ö, Benlioglu S (2009) Weed hosts of Verticillium dahliae in cotton fields in Turkey and characterization of $\mathrm{V}$. dahliae isolates from weeds Phytoparasitica 37:171-178 doi:10.1007/s12600-009-0027-6

Yohalem D, Passey T (2011) Amendment of soils with fresh and post-extraction lavender (Lavandula angustifolia) and lavandin (Lavandula $\times$ intermedia) reduce inoculum of Verticillium dahliae and inhibit wilt in strawberry Applied Soil Ecology 49:187-196 doi:http://dx.doi.org/10.1016/j.apsoil.2011.05.006

Yuan Y, Feng H, Wang L, Li Z, Shi Y, Zhao L, Feng Z, Zhu H (2017) Potential of Endophytic Fungi Isolated from Cotton Roots for Biological Control against Verticillium Wilt Disease PLoS ONE 12:e0170557 doi:10.1371/journal.pone.0170557

Zhang L, Wang M, Li N, Wang H, Qiu P, Pei L, Xu Z, Wang T, Gao E, Liu J, Liu S, Hu Q, Miao Y, Lindsey K, Tu L, Zhu L, Zhang X (2018) Long noncoding RNAs involve in resistance to Verticillium dahliae, a fungal disease in cotton Plant Biotechnology Journal 16:1172-1185 doi:10.1111/pbi.12861 